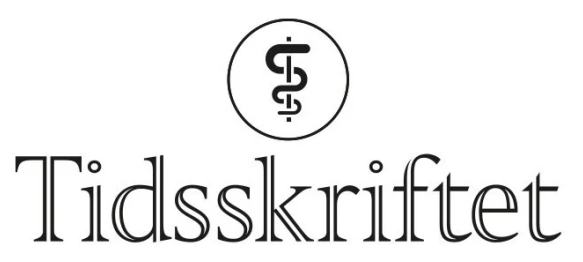

DEN NORSKE LEGEFORENING

\title{
Det blir ikke mer forskning av mer rapportering
}

KOMMENTAR

\section{JOHAN RAEDER}

Johan Ræder (born 1954), professor at the University of Oslo and medically responsible senior consultant at the Department of Anaesthesiology, Oslo University Hospital. He has served as an expert adviser in cases involving injury at various levels and for a number of government agencies, including the Norwegian System for Patient Injury Compensation.

The author has completed the ICMJE form and declares no conflicts of interest.

Email: johan.rader@medisin.uio.no

Are Brean har et innlegg i Tidsskriftet den 28. juni hvor han er opptatt av at norske kliniske studier i liten grad rapporteres til forskjellige nasjonale og internasjonale databaser (1). Det gis ingen oppskrift på hvordan dette skal bli bedre, annet enn at «noen» må ta seg sammen og sørge for at slik rapportering gjøres. I praksis vil dette bety at den enkelte forsker skal bruke ytterligere tid på ekstra byråkrati.

De siste årene har vi opplevd et stadig økende tilfang av velmente skjemaer som skal fylles ut, instanser som skal informeres og godkjenne, samt omfattende prosedyrer knyttet til overvåking og gjennomføring av klinisk forskning. Hvis man ønsker å gjøre en studie som innbefatter bruk av godkjente legemidler, er det følgende et minimum man må gjennom før oppstart: Regional Etisk Komité, Statens Legemiddelverk (SLV), personvern, ledelse på aktuelle institusjon(er) pluss eventuelle aktuelle universitet, datalagringstillatelse, datalagringsavtale, avtale om monitorering samt meldinger til EudraCT, ClinTrials (eller lignende) og Helsenorge.no. Alt dette kreves for en godkjent prospektiv randomisert studie. I praksis kan det føre til at klinikere som har lyst til å forske på aktuelle problemstillinger ved siden av sin travle kliniske hverdag, dropper hele prosjektet eller i stedet gjør en observasjonsstudie eller kvalitetsstudie. Disse krever betydelig mindre byråkrati i forkant, men gir dessverre betydelig dårligere vitenskapelig evidens og blir sjelden akseptert av anerkjente tidsskrifter.

Hovedproblemet er at det gjøres for få gode kliniske studier på legemidler og pasienter i Norge. Ifølge SLV ble det i 2020 bare søkt om totalt 50 studier totalt fra hele det norske medisinske miljøet av forskere som ikke arbeidet på oppdrag fra legemiddelindustrien. Tallet har vært stabilt på samme lave nivå de siste 20 årene $(\underline{1}, \underline{2})$. Dette til tross for massiv $\emptyset \mathrm{kning}$ i forskningsadministrative stillinger og sterke ønsker om økt aktivitet, nå sist i Nasjonal handlingsplan for kliniske studier. Kan det være slik at alle de som skal hjelpe til i 
stedet blir en kilde til forsinkelser, dobbeltarbeide og frustrasjon? I sin tid var det en visjon om «en postkasse» for de som skulle planlegge og få godkjent et forskningsprosjekt. Hvor er det blitt av den tanken?

Når det gjelder rapportering av de få studiene som faktisk gjøres, kan man imidlertid være nokså trygg på at forskere som har fullført en studie svært gjerne vil ha denne publisert i et anerkjent tidsskrift. Publikasjonen vil deretter gjenfinnes med et enkelt søk på Medline for alle som er interesserte. Det er imidlertid slik at tidsskriftene (inkludert Tidsskrift for Den norske legeforening) stort sett ikke godkjenner annen publisering, for eksempel en full rapport til et register i forkant. Rapportering må altså uansett vente, og da bør kanskje forskeren heller få lov til å fokusere på videre forskning?

Vi bør alle være enige om at vi trenger flere gode kliniske studier i Norge, men da bør svaret være mindre og enklere byråkrati og ikke det motsatte.

\section{LITTERATUR}

1. Brean A. Først registrere, så rapportere. Tidsskr Nor Legeforen 2021; 141. doi:10.4045/tidsskr.21.0502. [PubMed][CrossRef]

2. Statens Legemiddelverk. Oversikt over antallet søkte studier om klinisk utprøving. https://helseomsorg21monitor.no/figur/54 Lest 11.8.2021.

Publisert: 6. september 2021. Tidsskr Nor Legeforen. DOI: 10.4045/tidsskr.21.0585

(C) Tidsskrift for Den norske legeforening 2023. Lastet ned fra tidsskriftet.no 26. april 2023. 